\title{
LOOKING TOWARDS THE FUTURE: SOME CONCLUDING REMARKS
}

Bernard C Lategan

Stellenbosch University

\begin{abstract}
It is a temptation - which I shall resist - to comment on each of the very diverse and stimulating contributions to this volume of Scripura. I therefore apologise beforehand for not doing justice to the individual authors and to the full spectrum of their views. In stead, I shall try to highlight from a very personal perspective some aspects that may be of special significance for the future.
\end{abstract}

\section{Hamburg as catalyst}

As far as the DRC family is concerned, our German colleagues have served as catalysts for a sustained, inclusive and incisive dialogue within the family itself - against the backdrop of other religions and in constant interaction with international partners. The DRC represents just one focal point in a much wider picture, but the project has rendered an important service to this tradition. It helped to bring it in touch with itself again and by insisting that it does not relinquish its responsibility - towards the family itself, but also towards the deepening of a still very fragile democracy.

The results that have been achieved thus far not only underline the importance and relevance of the topic, but fully vindicate the decision of the Deutsche Forschungsgemeinschaft to invest in this Sonderforschungsgebiet.

\section{Developing a coherent theological discourse}

The challenge of Botman to the DRC to develop a coherent (and alternative) theological discourse post-1990 has been taken seriously. The contribution of Naude provides an important roadmap for its future development. At least four levels of this discourse need attention:

\subsection{Reclaiming the Reformed tradition}

The in-house theology of the DRC is in need of serious revitalisation. This will not be achieved by skilful redecoration or deft sleights of hand to make the church attractive to the 'spirit of the day'. It rather requires the deepening of theological reflection and the reclamation of the best the Reformed tradition has to offer. The starting point for this revitalisation should be the recognition of the universal relevance of Belhar both as an agenda and as a modus of engagement. The continuing reluctance in some circles to engage with the substance of the Confession deprives the DRC of a common starting point and of a workable re-entry into the theological debate.

\subsection{Engaging in the ecumenical discourse}

This is one of the promising areas where, as Smit shows, good progress has been made and which should be consistently pursued further. 


\subsection{Developing a critical public discourse}

This is no doubt the most difficult challenge, but at the same time of crucial importance if the DRC is to make a constructive contribution to the South African society that is now developing after 1994. It is on the one hand a matter of regaining a public confidence and on the other hand a matter of substance. As far as the first is concerned, it is good to remember that a public face has always been part of the Reformed tradition. As far as the second is concerned, a deeper understanding of human society is an indispensable prerequisite. A serious concern in this regard is the theological training of the DRC in its present form. The continuing isolation of theological education from the humanities and from the natural sciences for that matter is creating a situation where meaningful engagement becomes increasingly difficult. I am not referring to an overview of nontheological subjects from a theological perspective, but to an engagement with these disciplines on their own terms. There was a time when the church had the benefit of clergy who had first-hand knowledge of philosophy, psychology, literature, sociology, economics, political science and related fields, often on a postgraduate level. The present policy of "learning programmes" often has the opposite effect, with the result that theological inputs are not taken seriously by discussion partners - often with reason. Meaningful engagement on the level of public discourse will not be possible unless there is a willingness and a commitment to understand human society on its own terms and from the perspective of its own proponents.

A further distraction at this stage is the furore caused by the so-called 'new reformation' debate. On the one hand, it turns the attention inwards, in the sense that it continues the authority of Scripture debate that has been raging in the DRC for decades without any constructive resolution. On the other hand, it deals with a dated issue, in the sense that it is in essence an attempt to catch up and to confront the (church) public with the implications of the Enlightenment - a phase of intellectual development that many in South Africa have missed in their own thinking and experience.

The net result is that attention is diverted away from issues that are of critical importance for a public discourse (as identified by Naude and others) and that energy is expended on matters that are not central to the task.

\subsection{Widening the horizon to an African discourse}

Contributors from outside South Africa have challenged participants to change the community of discourse and to make it truly African. This is neither a romantic ideal nor a nostalgic longing based on 'out of Africa' sentiments. The reality of Africa is rapidly changing as part of new awakening and a re-assessment of its role in a global context. NEPAD and the proposed African Union are but two of the more visible manifestations of the new mood. The role of Christianity, of the church and of religion as such has always been ambiguous if not controversial in the course of the history of the continent. The present turmoil provides an unexpected opportunity to re-think and restructure this role as part of a wider social transformation.

\section{Closing the gap between discourse and reality}

Important as the development of a coherent theological discourse as an intellectual and theological challenge might be, we have also been constantly reminded that the gap between discourse and reality should be closed. A recurring theme in many of the contributions was the need to bring theological reflection in direct contact with the realities on the ground, especially because of the relative isolation in which the DRC family found 
itself for a considerable period of time. All the theological energy and discussion according to this perspective - will be of little value if the participants do not expose themselves to the complex, vibrant, fast moving, and often very confusing society we find ourselves in South Africa. Antjie Krog expressed the same sentiment in her poignant and very personal plea: 'Just change the statistics!' That is, change the statistics of how very few white South Africans have blacks compatriots as personal friends.

\section{Preparing for a new generation}

One of the most valuable contributions to the conference was the focus on the youth and the expected next generation of church members. The empirical findings with regard to belief patterns, church adherence, preferences and changing mindsets by Pieterse, McMaster, Gensicke and Buys presented a fascinating kaleidoscope of attitudes and orientations among a significant section of South African youth - a picture that is both disturbing and hope-giving. The characteristics of the 'Zoid generation' are indeed indicative of a change of mood, with mobility and the distrust of organised religion as prominent features. Diversity is embraced and celebrated, based on a new value system.

The deeper significance of these changes should not be missed: The youth is no longer willing to take their cue from the older generation - they take more direct responsibility for shaping the future. Gensicke correctly identifies the need for courageous leadership to break the historical isolation and to make the DRC youth part of the new and diverse South African society.

\section{Desiderata for the future}

When looking towards the future, certain issues stand out:

5.1 The quality of leadership in the DRC will be decisive - Smit provided a very sobering analysis and identified the main issues. Naude and Van Dyk spellt out the implications for leadership at synodical level. Will the leadership be found wanting or will they rise to the challenge?

5.2 The credibility of the church will be tested more stringently than ever before. For many members, two issues will play a major role in determining this credibility: The issue of church unity and the issue of gender. As far as the first is concerned, perhaps the moment has already passed to make a difference. Despite progress that has been made, there is at the same time a fatigue discernible in the unity debate - and a distrust that finds its origin in spurned love. As far as the second is concerned, the real hard gender issues still have to be faced - and the fact that the church has lost its credibility for many because of its inability to deal with these issues on a fundamental level.

5.3 The development of a constructive orientation towards the future. To overcome the inertia and self-pity, a different kind of historical consciousness will be required - a consciousness that will be able to deal with the past while reaching for the future. The TRC in its best moments has provided us with glimpses of what is possible - not to forgive and to forget, but to remember and at the same time to reconcile and to move together towards the future. Simply put: Will the DRC be a source of despondency or a source of hope? 
Three desiderata present themselves for the future:

- A sense of timing, that is, a historical consciousness that understands how destructive circumstances and events can be, but also knows how to seize the moment and the opportunity;

- A hermeneutics of difference, for which women and the marginalised are the best placed to be among its leading exponents; and

- A commitment to the liberation and re-humanisation of all (perpetrators and victims alike) who have been damaged by the events of the past. 